\title{
Strength Properties Forecast of Frozen Rocks by Logging Data (South Yakutia, Russia)
}

\author{
N.N. Grib* ${ }^{* 1}$, V.S. $\operatorname{Imaev}^{1,2}$ \\ ${ }^{1}$ Technical Institute (branch) North-Eastern Federal University \\ 67890, Neryungri,Yakutia (Russia) \\ ${ }^{2}$ Institute of the Earth Crust RAS, 664033 Irkutsk (Russia) \\ ${ }^{3}$ Diamond and Precious Metals Geology Institute, Siberian Division \\ Russian Academy of Science, Yakutsk, Yakutia (Russia) \\ "grib@nfygu.ru, ${ }^{2}$ imaev@crust.irk.ru
}

\begin{abstract}
Geological situation of the South-Yakutian coal-field is complex due to geocryological factors, e.g. overall development of insular permafrost.

Strength and indexes of permafrost rock are increasing for $30 \%$ at an average. Natural gamma-intensity $I_{\gamma}$ does not undergo practical changes in the process of epigenetic transformation of rock and cryogenic processes. Consequently, gamma-ray logging data $(G L)$ present the opportunity to evaluate argillaceous ness and lithologic composition, which have dominating effect on strength property of rock.
\end{abstract}

The structure and texture characteristic properties of the section are being evaluated by the data of borehole gauging. Data of borehole diameter variation during the drilling process may be regarded integral characteristic of rock strength.

Using multimeasuring correlations between geophysic parameters $I_{\gamma} \delta v$ and strength properties of rock $\sigma_{c m}$ and $\sigma_{c m}, \sigma_{t}$, are being studied the strength properties of permafrosted coal containing rock by the finding of logging.

Keywords: The South-Yakutian coal-field, coal bearing deposits, permafrost rock, strength, physical properties, elastic wave propagation velocity, electrical resistance, natural radioactivity, magnetic susceptibility, volume density, compression and tensile strength limits.

\section{INTRODUCTION}

In conditions of application of modern highly mechanized mining and drifting complexes in construction and exploitation of coal mining industry pits, demands for studies of strength properties of rock have been increasing.

Studies of strength of rock by means of core testing laboratory methods have number of essential disadvantages.

1. Testing is being provided optionally on sections of discrete boreholes, e.g. over the optional network.

2. Being drilled, mechanically soft rock is breaking and it is hardly possible to extract core from them. As a result, for strength property analysis only those cores are being tested in laboratory, which happened to hold their shape sufficiently. It results in artificial increase of strength indexes of the section, while soft rock, bedding in roof and seam floor of coal seam, are considered the most important subject of the research.

In order to enhance the validity of strength prognosis of rock and efficiency of coal exploration in the conditions of permafrost rock, within the South-Yakutian coal field there have been used to special technique, defining the strength of permafrost rock due to their natural state.

The South-Yakutian coal-field is the main base of coking coal in the East of Russia. The area of coal field within the borders of development of mezozoic coal bearing deposits constitutes 26 thousand squire kilometers. 
Coalbearing deposits are being presented by monotonic considerably transformed aleuro-sand rock, which is referred, according to petrophysical classification of professor V.V.Grechukhin, to VIII - XI stages of coal bearing deposit transformation [1].

Geological situation of the field is complex due to geocryological factors, e.g. overall development of insular permafrost. Permafrost rock has intermittent spread by area and entire spread by vertical. The thickness of permafrosted rock varies from the first meters up to 200 meters.

In general, there is a range of the temperature variation of permafrost rock from $0^{\circ} \mathrm{C}$ to $-4^{\circ} \mathrm{C}$ within present coal field. Permafrosted seams with temperature from $0^{\circ} \mathrm{C}$ to $-2^{\circ} \mathrm{C}$ are widespread. The thickness of seasonal frost penetration varies from 1.5-2 meters.

Strength, as well as physical properties have been formed under the influence of both groups of factors: primary (genetic) and secondary process of rock transformation.

There is a number of factors attributed to the primary factors: material and grain-size analysis, texture, structure, primary material attribution, type and composition of cement, organic impurities [1].

By the feature of material composition coalbearing rock can be divided into clay, carbonate and fragmental rocks. Of all these rocks, clay rock has the lowest strength properties, while carbonate rock and silicificated fragmental rock have the highest strength index.

Strength properties of rock are being cosiderably affected by the cement of this rock. Rocks with carbonate cement or secondary silicification are specified by high index strengh properties. Increase of clay cement content in rock is accompanied by decrease in strength properties.

Structure and texture characteristic properties of rock have considerable effect on strength of rock. Usually thin lamination of rocks reduces their strength, especially if there are interlayers of coal argillite. There is an increase in jointing of thin laminated rock, which evokes additional reduction of rock strength $[2,4]$.

The secondary factors affecting rock strength are processes of diagenesis, epigenesis and metagenesis appearing under the affect of overlapping rock mass pressure and temperature, determined by geothermal gradient and particular paleodepth [1].

Table1. Average values of physical and mechanical properties of the frozen rock in the South-Yakutian coal field ( Elga's coal deposit)

\begin{tabular}{|c|c|c|c|c|c|c|c|c|c|c|}
\hline $\begin{array}{c}\text { Phys.-mech. } \\
\text { Properties }\end{array}$ & $\begin{array}{c}\text { Coarse grained } \\
\text { sandstone }\end{array}$ & \multicolumn{2}{c|}{$\begin{array}{c}\text { Medium grained } \\
\text { sandstone }\end{array}$} & \multicolumn{2}{c|}{$\begin{array}{c}\text { Fine drained } \\
\text { sandstone }\end{array}$} & \multicolumn{2}{c|}{ Aleurolits } & \multicolumn{2}{c|}{$\begin{array}{c}\text { Coal } \mathrm{A}^{\mathrm{d}}=15 \% \\
\text { absolute }\end{array}$} \\
\hline & $\begin{array}{c}\text { Thawe } \\
\mathrm{d}\end{array}$ & $\begin{array}{c}\text { perma } \\
\text { frosted }\end{array}$ & thawed & $\begin{array}{c}\text { perma - } \\
\text { frosted }\end{array}$ & Thawed & $\begin{array}{c}\text { perma - } \\
\text { frosted }\end{array}$ & thawed & $\begin{array}{c}\text { perma - } \\
\text { frosted }\end{array}$ & thawed & $\begin{array}{c}\text { perma - } \\
\text { frosted }\end{array}$ \\
\hline $\mathrm{V}_{\mathrm{p}}, \mathrm{m} / \mathrm{s}$ & 4100 & 5000 & 4570 & 5200 & 4700 & 5600 & 2850 & 4500 & 2200 & 3500 \\
\hline$\rho, \Omega \mathrm{m}$ & 750 & 4950 & 450 & 2930 & 275 & 1520 & 150 & 1200 & 7500 & 9000 \\
\hline $\mathrm{I}_{\gamma}, \mathrm{pA} / \mathrm{kg}$ & 0.5 & 0.5 & 0.72 & 0.72 & 0.86 & 0.86 & 1.08 & 1.08 & 0.36 & 0.36 \\
\hline $\begin{array}{c}\chi \mathrm{unit} \mathrm{CI} \times 10^{-5} \\
\mathrm{un}\end{array}$ & 8 & 8 & 12 & 12 & 18 & 18 & 38 & 38 & 3 & 3 \\
\hline$\delta \mathrm{v}, \mathrm{g} / \mathrm{sm}^{3}$ & 2.45 & 2.45 & 2.58 & 2.58 & 2.63 & 2.62 & 2.61 & 2.61 & 1.37 & 1.37 \\
\hline$\sigma_{\mathrm{cm}}, \mathrm{mPa}$ & 57 & 79 & 65 & 87 & 72 & 91.3 & 50 & 72 & - & - \\
\hline$\sigma_{\mathrm{t}}, \mathrm{mPa}$ & 6.3 & 9.2 & 7.8 & 11.0 & 10.3 & 12.1 & 6.7 & 9.9 & - & - \\
\hline
\end{tabular}

Note: thawed $-t>0^{0} C$, permafrosted $0^{0}>t<-4^{0} C, V_{p}$ - elastic wave propagation velocity, $\rho$ - electrical resistance, $I_{\gamma}$-natural radioactivity, $\chi$ - magnetic susceptibility, $\quad \delta_{v}$ - volume density, $\sigma_{c m}$, $\sigma_{t}$-compression and tensile strength limits.

With submersion of rock the density increase and porosity decrease take place, accompanied by increase of volume density, elastic wave propagation velocity, increase of strength and deformation properties. These kinds of transformation are irreversible. Therefore, physical and chemical properties of rocks are being specified by the indexes attained at maximum pressure and temperature values, i.e. at the maximum depth of their submersion. Subsequent raise of rock do not cause changes in physical and chemical properties. Established assosiations and mechanisms become violated in zones with 


\section{N.N. Grib \& V.S. Imaev}

widespread permafrost rock. In comparison with those of thawed rock, strength and elasticity indexes of permafrost rock are increasing by $30 \%$ on an average. The difference of physical properties between different lithologic types of permafrost enclosing rocks and coal is considerably reducing. Cryogenic processes do not influence volume density and magnetic susceptibility. Natural gamma-intensity $\mathbf{I}_{\gamma}$ does not undergo practical changes in the process of epigenetic transformation of rock and cryogenic processes, while the rest of the mentioned parameters (Table 1) are changing.

Consequently, gamma-ray logging data (GL) present the opportunity to evaluate argillaceousness and lithologic composition, which have dominating effect on strength property of particular rock that constitute sections of boreholes in permafrost rock.

For more precise definition of lithologic composition and zones of broken rock, there is a logging of magnetic susceptibility to be used (LMS), as far as magnetic susceptibility of rock is not affected by cryogenic processes [3].

The structure and texture characteristic properties of the section are being evaluated by the data of borehole gauging. Data of borehole diameter variation during the drilling process may be regarded as an integral characteristic of rock strength.

By the feature of borehole diameter variation during drilling, coalbearing rocks can be divided into two types.

Attributed to the first type are those rocks (dense carbonate sandstone, conglomerate, silicificated sandstone), where borehole diameter practically does not deviate from rated.

Attributed to the second type are most of rock (bituminous coal, argillite, argillaceous sandstone), which being drilled through collaps boreholes, diameters increase by 1.3-1.8 times, and there are cavities formed on some borehole intervals with virtual diameter $\delta v$, that is exceeding rated borehole diameter 2-3 times.

Therefore, relationship of borehole diameter variation with the lithologic composition of rock in the drilling process is to be observed.

From the borehole gauging data analysis, it follows that with the identical conditions of drilling there is an extension of borehole diameter to be observed: a) with the increase of organic impurity content in rock; b) with the increase of argillaceous cement content; c) with the decrease of carbonate cement content, all these factors are being effected on gamma-ray logging diagram by increase or decrease of natural gamma $\gamma$-intensity.

With the same conditions, there is a change of uniaxial compression strength $\sigma_{\mathrm{cm}}$ and uniaxial tensile strength $\sigma_{t}$ to take place.

Therefore, variation of natural radioactivity of rocks and borehole diameter depend on rock strength, and utilizing multimeasuring correlations between geophysic parameters $I_{\gamma}, \delta v$ and strength properties of rock $\sigma_{\mathrm{cm}}$ and $\sigma_{\mathrm{t}}$, it gives the possibility to study with certain precision the strength properties of permafrosted coalcontaining rock by the finding of logging.

For the approximating function the following exponential function is to be chosen:

where $y_{i}$ - one of the strength parameters;

$y_{i}=\sum_{i=n}^{n} C_{i} \cdot 10^{a_{i 0}+a_{i 1} x_{i 1}+a_{i 2} x_{i 2} \ldots}$

$\mathrm{x}_{\mathrm{i} 1}, \mathrm{x}_{\mathrm{i} 2}$ - geophysic parameters;

$\mathrm{a}_{\mathrm{i} 0}-\mathrm{a}_{\mathrm{i} 2}$ - polynomial coefficient;

Type of the function (1) has been chosen on the basis of regression analysis of strength parameters of diffrent lithologic types. Coefficients of the equation (1) for the definite coal field are being calculated 
by the method of least squares, with utilization of particular ultimate strength values obtained in laboratory by core testing.

Thus, for Elga coal deposit there are following equations of evaluation $\sigma_{\mathrm{cm}}$ and $\sigma_{\mathrm{t}}$ of permafrosted coal rock:

$\sigma_{c m}=0.4605 \times 10^{4.1-\frac{d_{y}-0.5 \Delta H^{0.63}}{d_{r}}}+0.4605 \times 10^{-2.3 \Delta I_{y}+3.1}$

$\sigma_{c m}=0.5 \times 10^{3.1-\frac{d_{y}-0.5 \Delta H^{0.63}}{d_{r}}}+0.5 \times 10^{-2.3 \Delta I_{y}+2.1}$

where $\Delta \mathrm{H}$ - difference between borehole depth and depth of virtual measurement being conducted.

$\mathrm{I}_{\gamma^{-}}$normalized value of natural radioactivity, in relative units;

$\delta_{\mathrm{r}}, \delta v$ - rated and virtual borehole diameters

Reliability of evaluation of strength by logging finding was checked by being compared with the results of laboratory core testing.

There is persentage root-mean-square error of strength property evaluation: for $\sigma_{\mathrm{cm}}-\delta=13 \%$, for $\sigma_{\mathrm{t}}$ $\sigma=11 \%$.

This work was supported by grant of Ministry of educations and Sciences of Russian Federation ( State task in the field of scientific activity N 5.1771.2014/K ) and by grant of Russian Science Foundation (RSF) N 15-17-20000.

\section{REFERENCES}

[1] Grechukhin V.V. Petrophysics of coalcontaining formations. "Nedra" Publishing House, Moscow, 1990, p.468 (in Russian).

[2] Grechukhin V.V. Geophysical methods of research in coal deposit geology. "Nedra" Publishing House, Moscow, 1995, p.476. (in Russian)

[3] Grib N.N. Experience of application of magnetic susceptibility logging in studies of coalcontaining deposits within the South-Yakutian coal field. Thesis for International Geophysic Conference. Saint-Petersburg, 1995, p. 243-247 (in Russian).

[4] Shtumf G.G., Ryijkov U.A., Shalamov V.A., Petov A.I. Physical and technical properties of rock and coal of Kuznetski coal field. "Nedra" Publishing House, Moscow, 1994, p.447. (in Russian). 


\section{AUTHORS' BIOGRAPHY}

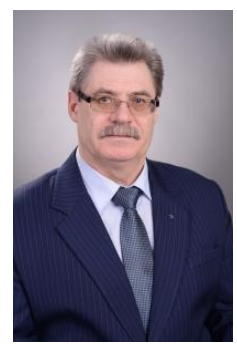

Grib Nikolay Nikolaevich - is a deputy of director of Technical institute (branch) the North-Eastern Federal University in Neruyngri sity

On the advanced study - Professor, Doctor of sciences

Area of scientific interests: studies of engineer-geological terms of coal deposits and quality of coals by geophysical methods, natural and technogenic сейсмичность.

In the advanced studies Grib Nikokay N.H the methods of decision of such issues of the day, as prognosis of indexes of quality of coals and mining and geological conditions of coal deposits, are offered from geophysical data on the stages of secret service and working mine in the conditions of Kryolitozone; he is work out technology of changeability of phisical - mechanical properties of coal-deposits breeds and on her basis a management method is worked out by explosive works on coal deposits The more than 300 advanced studies are an author and coauthor, including 8 monographs.

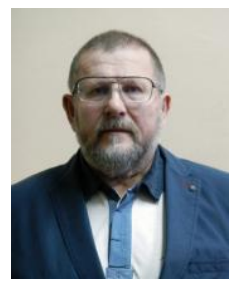

Imaev Valery Suleimanovich, chief researcher of the laboratory of earthquake engineering and seismology, Institute of Earth Crust Siberian branch of the Russian Academy of Sciences in Irkutsk sity. At the same time is a Professor at the Technical Institute (branch) of North-Eastern- Federal University (visitor-Professor part-time) Area of scientific interests - modern geological processes occurring in the large coal deposits of the North-East of Russia as well as establishing the level of seismic hazard and the change in threat level during the operation of the mine fields and underground mines in earthquake-prone areas of the Russian Arctic in scientific works. With the proposed methods In seismotectonic analysis of the territory of Yakutia and the definition of levels of seismic threat of major mineral deposits of the Republic of Sakha(Yakutia) he developed methods for studying and mapping of active faults proposed ways to reduce the potential hazard these faults $\mathrm{He}$ is the author or co-author of 250 scientific works including 7 monographs. 